\title{
In vitro Studies on a-Amylase and a-Glucosidase Inhibitory Activity of Some Bioactive Extracts
}

\author{
Sayyada Saleha Momina, Vanapatla Swaroopa Rani* \\ Department of Pharmacognosy and Phytochemistry, University College of Pharmaceutical Sciences, Kakatiya University, Warangal, Telangana, INDIA.
}

\begin{abstract}
Objectives: To investigate the therapeutic effects of methanolic leaf extracts of Lindernia ciliata, Phyllanthus reticulatus and Bambusa vulgaris were evaluated for their effect on $\alpha$-amylase and $\alpha$-glucosidase inhibition by using in vitro assays. Methods: Leaves of Lindernia ciliata, Phyllanthus reticulatus and Bambusa vulgaris extracted with methanol and these extracts are concentrated under reduced pressure. The inhibitory effect of these extracts on $\alpha$-amylase and $\alpha$-glucosidase inhibitory activities as well as some antioxidant parameters was determined in vitro. Results: The results revealed that these methanolic bioactive extracts inhibited $\alpha$-amylase and $\alpha$-glucosidase activities in a dose dependent manner. The plant extracts were used at varying concentrations to ensure which concentration of the extract causes the most inhibition. Among all, Lindernia ciliata has shown the prominent enzyme inhibitory activity (for $\alpha$-amylase $I_{50} 6.11 \mathrm{mg} / \mathrm{ml}$ and for $\alpha$-glucosidase $6.10 \mathrm{mg} / \mathrm{ml}$ ) and was well comparable with the standard drug acarbose (for $\alpha$-amylase $I_{50} 5.03 \mathrm{mg} / \mathrm{ml}$ and for $\alpha$-glucosidase $I C_{50} 5.13 \mathrm{mg} / \mathrm{ml}$ ). Phytochemical analysis of the extracts indicated the presence of alkaloids, flavonoids, steroids/triterpenoids and their glycosides, tannins, coumarins, sterols and fatty alcohols. Further,
\end{abstract}

the total phenolic and total flavonoid contents were estimated. These results substantiate the use of Lindernia ciliata in traditional medicine for the treatment of diabetes by controlling postprandial hyperglycemia. Conclusion: The antioxidant properties and enzyme inhibition could be part of the mechanism by which they are used in the treatment/prevention of type-2 diabetes. These findings suggest that the plants may be a potential source for the development of new oral hypoglycemic agent.

Key words: Acarbose, Bambusa vulgaris, Lindernia ciliata, Phyllanthus reticulatus, $\alpha$-amylase, $\alpha$-glucosidase.

\section{Correspondence}

Vanapatla Swaroopa Rani,

Assistant Professor, Department of Pharmacognosy and Phytochemistry, University College of Pharmaceutical Sciences, Kakatiya University, Warangal 506009, Telangana, INDIA.

Phone: +917981754379

Email: swarooparanivanapatla@gmail.com

DOI: 10.5530/jyp.2020.12s.50

\section{INTRODUCTION}

Diabetes mellitus is a metabolic disorder characterized by chronic hyperglycemia with disturbances in carbohydrate, fat and protein metabolism resulting from defects in insulin secretion (type $1 \mathrm{DM}$ ) or insulin action (type $2 \mathrm{DM}$ ) or both. ${ }^{1}$ Diabetes can be classified into three major categories: type 1 diabetes, type 2 diabetes and gestational diabetes mellitus. Type- 2 diabetes mellitus is a common metabolic disorder and one of the therapeutic approach for this disease is the maintenance of normal blood glucose levels after meal. Postprandial hyperglycemia plays an important role in the development of type- 2 diabetes and its complications. ${ }^{2}$

Globally, there is rapid increase in people affected with diabetes due to an array of clinical factors like aging, smoking, unhealthy diet, hyperlipidemia and sedentary life style. ${ }^{3}$ WHO estimates that diabetes was the seventh leading cause of death in 2019. Based on the report cited by International Diabetes Federation (2019), diabetes mellitus is the major cause of mortality and morbidity, with a projected range of 463 million adults being affected and 4.2 million people died in 2019 . In 2045, the incidence of the disease is to be about 700 million and the prevalence will be higher in developing countries (Africa, Asia and South America) with low and middle-incomes. ${ }^{4}$

Hypoglycemic activity of therapeutic plants is because of their capacity to restore the pancreatic tissues by bringing about an increment in insulin yield, hindering the intestinal ingestion of glucose or encouraging metabolites in insulin subordinate processes. ${ }^{5}$ Treatment of type 2 diabetes improves patient blood sugar levels and insulin secretion stimulated by drugs such as a-glucosidase inhibitors and metformin. ${ }^{6}$ Improvement of the activity of insulin at the objective tissues, with the utilization of sensitizers (biguanides, thiazolidinediones); incitement of endogenous insulin discharge with the utilization of sulfonylureas (glibenclamide, glimepiride) and a decrease of the interest for insulin utilizing particular enzyme inhibitors (acarbose, miglitol). For the best of my knowledge, previous studies have not investigated the $\alpha$-amylase and $\alpha$-glucosidase enzyme inhibitory activities of Lindernia ciliata, Phyllanthus reticulatus and Bambusa vulgaris. Therefore, this work was undertaken to evaluate the probable mechanism behind its hypoglycemic activity.

\section{MATERIALS AND METHODS}

\section{Collection of plant materials}

Lindernia ciliata, Phyllanthus reticulatus and Bambusa vulgaris were collected in August 2019 from Kakatiya University campus, Warangal, Telangana, India and authenticated by Dr. V.S. Raju (taxonomist), Department of Botany, Kakatiya University and Warangal. The Voucher specimen of these plants is deposited in the Department of Pharmacognosy, University College of Pharmaceutical Sciences, Warangal, Telangana, India.

\section{Preparation of methanolic extracts}

The leaves of Lindernia ciliata, Phyllanthus reticulatus and Bambusa vulgaris $(1 \mathrm{~kg})$ were collected, washed under running tap water, dried under shade, ground into coarse powder and then macerated 
with methanol at room temperature. After exhaustive extraction, the methanolic extracts were concentrated under reduced pressure (Rotavapour, Switzerland) to yield green coloured mass.

\section{Chemicals}

$\alpha$-amylase (porcine pancreas), $\alpha$-Glucosidase (Saccharomyces cerevisiae), P-nitro phenyl $\alpha$-D-glucopyranoside, 3,5-Dinitro-salicylic acid, acarbose, sodium carbonate, sodium potassium tartarate, sodium dihydrogen phosphate, potassium dihydrogen phosphate, di-sodium hydrogen phosphate and di-potassium hydrogen phosphate, sodium hydroxide were procured from Gamut Scientifics (SRL), Secunderabad, India. Folin-ciocalteu reagent from Hi-media (Mumbai, India). All other chemicals and solvents used are of analytical grade.

\section{Phytochemical Screening}

The methanolic leaf extracts of Lindernia ciliata, Phyllanthus reticulatus, Bambusa vulgaris were subjected to phytochemical screening using dried samples for the presence of different classes of organic compounds like alkaloids, flavonoids, steroids/triterpenoids, carbohydrates, tannins, saponins, phenolic compounds etc.

\section{Determination of Total phenolic content and Total flavonoid content Total phenolic content}

The total phenolic content of the extract was determined using Folinciocalteu colorimetric method as described in the literature. ${ }^{7}$ The extract $(100-1000 \mu \mathrm{g} / \mathrm{ml})$ or standard solution of gallic acid $(10-100 \mu \mathrm{g} / \mathrm{ml})$ was added to $25 \mathrm{ml}$ volumetric flask containing $9 \mathrm{ml}$ of distilled water. A reagent blank was prepared using distilled water instead of a sample. $1 \mathrm{ml}$ of Folin-ciocalteus phenol reagent was added to the mixture and shaken. After $5 \mathrm{~min}, 10 \mathrm{ml}$ of $7 \%$ aqueous sodium carbonate solution was added to the mixture. The solution was diluted to $25 \mathrm{ml}$ with double distilled water and mixed. After incubation for $90 \mathrm{~min}$ at room temperature, the absorption against prepared reagent blank was determined at $760 \mathrm{~nm}$ (ELICO SL159 UV-Visible Spectrophotometer). Quantification was done concerning the standard gallic acid and expressed as gallic acid equivalent (GAE) in mg per gram of extract.

\section{Total flavonoid content}

The total flavonoid content of the extract was measured by the aluminum chloride colorimetric method as described in the literature. ${ }^{8}$ Extract $(10-100 \mu \mathrm{g} / \mathrm{ml})$ or standard solution of Rutin $(10-100 \mu \mathrm{g} / \mathrm{ml})$ was added to $10 \mathrm{ml}$ volumetric flask containing $4 \mathrm{ml}$ double distilled water. To the flask $0.3 \mathrm{ml}$ of $5 \%$, sodium nitrite solution was added. After $5 \mathrm{~min}$, $0.3 \mathrm{ml}$ of $10 \%$ aluminum chloride solution was added at 6 th $\mathrm{min}, 2 \mathrm{ml}$ of $1 \mathrm{M} \mathrm{NaOH}$ was added and the total volume was made up to $10 \mathrm{ml}$ with double distilled water. The solution was mixed well and the absorbance was measured against prepared reagent blank at $510 \mathrm{~nm}$ (ELICO SL159 UV-Visible Spectrophotometer). The total flavonoid content was expressed as Rutin equivalent in mg per gram of extract.

\section{a - Amylase Inhibition Assay}

This assay was carried out by using a modified procedure of McCue and Shetty. ${ }^{9}$ Stock solution of extracts was prepared by dissolving up to $10 \mathrm{mg}$ of each extract in $1 \mathrm{ml}$ of DMSO. A total of $250 \mu \mathrm{L}$ of extracts $(1.25-10 \mathrm{mg} /$ $\mathrm{mL}$ ) was placed in a tube and $250 \mu \mathrm{L}$ of $0.02 \mathrm{M}$ sodium phosphate buffer (pH6.9) containing a-amylase solution $(0.5 \mathrm{mg} / \mathrm{ml})$ was added. This solution was pre-incubated in at $25^{\circ} \mathrm{C}$ for $10 \mathrm{~min}$, after which $250 \mu \mathrm{L}$ of $1 \%$ starch solution in $0.02 \mathrm{M}$ sodium phosphate buffer ( $\mathrm{pH} 6.9$ ) was added at particular time intervals and then further incubated at $25^{\circ} \mathrm{C}$ for $10 \mathrm{~min}$. The reaction was terminated by adding $500 \mathrm{~mL}$ of Dinitrosalicylic acid
(DNS) reagent. The tubes were then incubated in boiling water for $5 \mathrm{~min}$ and cooled to room temperature. The reaction mixture was diluted with $5 \mathrm{~mL}$ of distilled water and the absorbance was measured at $540 \mathrm{~nm}$ using (ELICO SL159 UV-Visible Spectrophotometer). A control was prepared using the same procedure replacing the extract with distilled water.

$\%$ Inhibition $\left[\left(\right.\right.$ Absorbance $_{\text {control }}-$ Absorbance $\left._{\text {extract }}\right) /$ Absorbance $\left._{\text {control }}\right] \times 100$

\section{a - Glucosidase Inhibition Assay}

The alpha-glucosidase inhibitory activity was determined according to the method described by Apostolidis with some modifications. ${ }^{10}$ Stock solutions of extracts were prepared by dissolving up to $10 \mathrm{mg}$ of each extract in $1 \mathrm{ml}$ of DMSO. A total of $50 \mu \mathrm{L}$ of extracts $(1.25-10 \mathrm{mg} / \mathrm{mL})$ and $100 \mathrm{~mL}$ of yeast alpha glucosidase solution in phosphate buffer $(\mathrm{pH}-6.9)$ were incubated at $25^{\circ} \mathrm{C}$ for 10 minutes followed by the addition of $50 \mathrm{~mL}$ of $5 \mathrm{Mmol} / \mathrm{L}$ p-nitrophenyl-alpha-D-glucopyranoside solution in $0.1 \mathrm{M}$ phosphate buffer (pH6.9). The reaction mixture was then incubated at $25^{\circ} \mathrm{C}$ for $5 \mathrm{~min}$ the reaction was terminated by adding $3 \mathrm{~mL}$ of $100 \mathrm{Mm}$ sodium carbonate solution into the mixture to stop the reaction and absorbance of liberated p-nitrophenol was read at 405nm using (ELICO SL159 UV-Visible Spectrophotometer). Acarbose was used a positive control (standard) and the inhibitory activity of alpha-amylase and alpha-glucosidase were calculated by using the following formula

$\%$ Inhibition $=\left[\left(\right.\right.$ Absorbance $_{\text {control }}-$ Absorbance $\left._{\text {extract }}\right) /$ Absorbance $\left._{\text {control }}\right] \times 100$

The $\mathrm{IC}_{50}$ values defined as the concentration of the extract that inhibited $50 \%$ of the enzyme activity were determined from plots of $\%$ inhibition versus log inhibitor concentration and calculated by logarithmic regression analysis from the mean inhibitory values.

\section{RESULTS}

\section{Preliminary phytochemical screening of methanolic} extracts

The preliminary phytochemical screening showed the presence of different phytoconstituents such as alkaloids, carbohydrates, flavonoids, phenolic compounds, steroidal/triterpenoid compounds and their glycosides, saponins, tannins in the methanolic leaf extracts of Lindernia ciliata, Phyllanthus reticulatus and Bambusa vulgaris. Results are shown in Table 1.

\section{Total phenolic content and Total flavonoid content}

The concentration of polyphenols present in the extracts is calculated by using a standard curve prepared with Gallic acid. The total phenolic content of methanolic extracts of Lindernia ciliata, Phyllanthus reticulatus, Bambusa vulgaris was found to be $75.6 \mathrm{mg}, 47.5 \mathrm{mg}$ and $39.4 \mathrm{mg}$ of GA equivalent per gram of extract respectively.

Table 1: Phytochemical constituents identified in methanolic leaf extracts of Lindernia ciliata, Phyllanthus reticulatus and Bambusa vulgaris.

\begin{tabular}{cccc}
\hline Class of chemical constituents and its tests & LCME & PRME & BVME \\
\hline Alkaloids & - & + & + \\
Flavonoids & + & + & + \\
Steroids/triterpenoids & + & + & - \\
Carbohydrates & + & + & - \\
Saponins & + & + & - \\
Phenolic compounds & + & + & + \\
Tannins & - & - & + \\
\hline
\end{tabular}

+: Present, -: Absent 
The concentration of flavonoid content present in the extracts is calculated by using a standard curve prepared with Rutin. The total flavonoid content of methanolic extracts of Lindernia ciliata, Phyllanthus reticulatus, Bambusa vulgaris was found to be $35.0 \mathrm{mg}, 23.1 \mathrm{mg}$ and $15.2 \mathrm{mg}$ of Rutin equivalent per gram of extract respectively. Among the three methanolic bioactive extracts, total phenolic and flavonoid contents were found to be more in Lindernia ciliata. Results are shown in Table 2.

\section{In vitro a-Amylase and a-Glucosidase Inhibitory Activity}

In the present study, methanolic leaf extracts of Lindernia ciliata, Phyllanthus reticulatus, Bambusa vulgaris and acarbose were evaluated for their inhibitory effect on $\alpha$-amylase and $\alpha$-glucosidase enzymes by the in-vitro method. The methanolic extracts of Lindernia ciliata, Phyllanthus reticulatus, Bambusa vulgaris and standard drug Acarbose at a concentration of $10 \mathrm{mg} / \mathrm{ml}$ exhibited $83.1 \%, 72 \%, 69.5 \%, 97.3 \%$ a-amylase inhibitory activity shown in Figure 1 and $82.8 \%, 70.8 \%$, $64.3 \%, 96.1 \%$ a-glucosidase inhibitory activity shown in Figure 2 respectively. Acarbose was used as a standard reference drug, which showed a-amylase inhibitory activity with an $\mathrm{IC}_{50}$ value of $5.03 \mathrm{mg} / \mathrm{ml}$ and $\alpha$-glucosidase inhibitory activity with an $\mathrm{IC}_{50}$ value of $5.13 \mathrm{mg} / \mathrm{ml}$. Among all the test samples, Lindernia ciliata has shown the prominent enzyme inhibitory activity with $\mathrm{IC}_{50} 6.11 \mathrm{mg} / \mathrm{ml}$ ( $\alpha$-amylase) and $6.10 \mathrm{mg} / \mathrm{ml}$ (a-glucosidase) which were well comparable with that of standard drug acarbose.

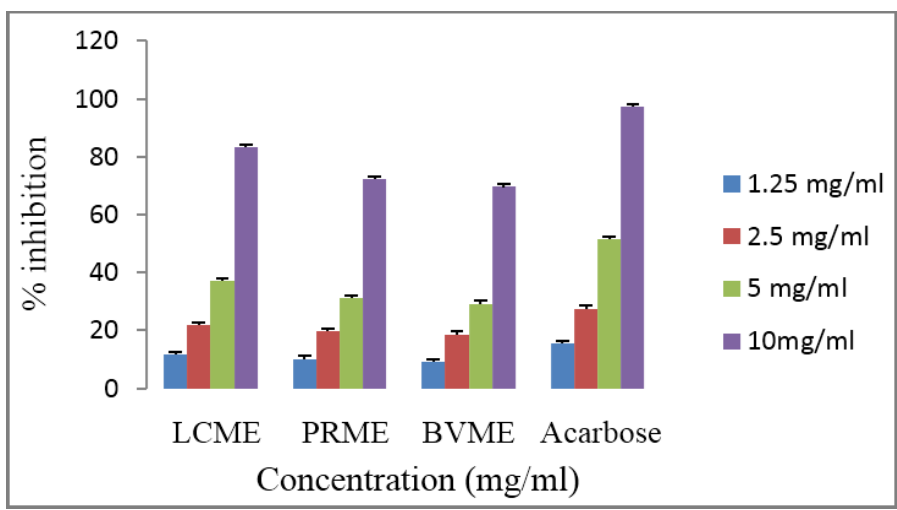

Figure 1: Porcine pancreatic $a$-amylase inhibition by methanolic leaf extracts of Lindernia ciliata, Phyllanthus reticulatus, Bambusa vulgaris (LCME, PRME, BVME) and acarbose. Data expressed as mean $\pm S D,(n=3)$.

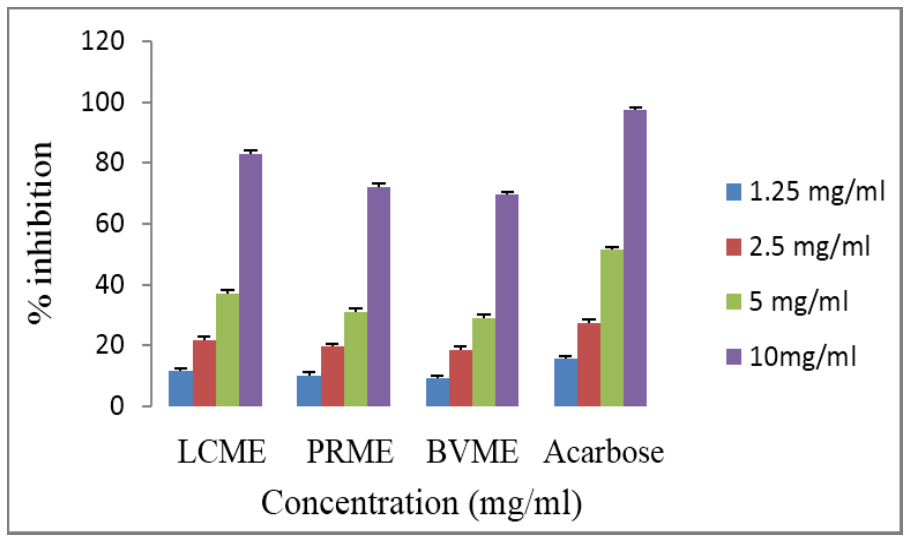

Figure 2: Yeast a-glucosidase inhibition by methanolic leaf extracts of Lindernia ciliata, Phyllanthus reticulatus, Bambusa vulgaris (LCME, PRME, BVME) and acarbose. Data expressed as mean $\pm S D$, $(n=3)$.
Table 2: Total phenolic and flavonoid content of Lindernia ciliata, Phyllanthus reticulatus and Bambusa vulgaris.

\begin{tabular}{ccc}
\hline $\begin{array}{c}\text { Methanolic } \\
\text { plant extracts }\end{array}$ & $\begin{array}{c}\text { Total phenolic content } \\
\text { (mg of GAE/gm of extract) }\end{array}$ & $\begin{array}{c}\text { Total flavonoid content } \\
\text { (mg of RE/gm of extract) }\end{array}$ \\
\hline LCME & $75.6 \pm 0.39$ & $35.0 \pm 0.22$ \\
PRME & $47.5 \pm 0.68$ & $23.1 \pm 0.58$ \\
BVME & $39.4 \pm 0.47$ & $15.2 \pm 0.31$ \\
\hline
\end{tabular}

Values represent mean \pm standard deviation of triplicate experiments

\section{DISCUSSION}

Management of the blood glucose level is a critical strategy in the control of diabetic complications. Inhibitors of saccharide hydrolysing enzymes (alpha-amylase and alphaglucosidase) have been useful as oral hypoglycemic agents for the control of hyperglycemia especially in patients with type- 2 diabetes mellitus. ${ }^{11}$ Inhibition of these enzymes delay carbohydrate digestion and prolong overall carbohydrate digestion time, causing a reduction in the rate of glucose absorption and consequently reducing the postprandial plasma glucose rise. ${ }^{12}$ Alpha-amylase is one of the main enzyme in the human body which is responsible for the breakdown of starch to more simple sugars. Alpha-amylase hydrolyze complex polysaccharides to produce oligosaccharides and disaccharides which are then hydrolyzed by alpha-glucosidase to monosaccharide and are absorbed through the small intestines into hepatic portal vein therefore increases postprandial blood glucose levels. ${ }^{13}$

Preliminary phytochemical screening of methanolic leaf extracts of Lindernia ciliata, Phyllanthus reticulatus revealed the presence of flavonoids, steroids/triterpenoids and their glycosides, carbohydrates, saponins and phenolic compounds. While, the methanolic leaf extract of Bambsa vulgaris contains alkaloids, flavonoids, tannins and phenolic compounds.

The inhibitory properties of alpha-amylase and alpha-glucosidase by these plant extracts may be useful in minimizing various side effects like flatulence, abdominal distention, meteorism and possibly diarrhoea with that of synthetic drugs. ${ }^{14}$ Present study suggests that one of the mechanism by which Lindernia ciliata, Phyllanthus reticulatus and Bambusa vulgaris exhibited its anti-hyperglycemic potential is through the inhibition of alpha-amylase and alpha-glucosidase enzymes. The inhibitory effects of methanolic leaf extracts of Lindernia ciliata, Phyllanthus reticulatus, Bambusa vulgaris against porcine pancreatic alpha-amylase and yeast alpha-glucosidase were evaluated in comparison with the reference anti-diabetic drug Acarbose.

Lindernia ciliata showed most active alpha-amylase and alpha-glucosidase inhibitory activities with $\mathrm{IC}_{50}$ values of $6.11 \mathrm{mg} / \mathrm{ml}$ and $6.10 \mathrm{mg} / \mathrm{ml}$ respectively. It is observed that the prominent percentage of inhibitory effect on both $\alpha$-amylase and $\alpha$-glucosidase enzymes by the methanolic leaf extract of Lindernia ciliata could be due to a major amount of total phenol and total flavonoid content found in this extract. $\alpha$-amylase and a-glucosidase enzyme inhibitory activity of methanolic leaf extracts of Lindernia ciliata, Phyllanthus reticulatus, Bambsa vulgaris were found to be in the order: LCME> PRME > BVME.

The results of the study elaborated scientific support regarding the use of three methanolic bioactive extracts i.e., Lindernia ciliata, Phyllanthus reticulatus and Bambusa vulgaris to treat diabetes through a mechanism based on its alpha amylase and alpha glucosidase enzyme inhibitory activity and this therapeutic potentiality could be exploited in the management of postprandial hyperglycemia in the treatment of type 2 diabetes mellitus. However, further studies are needed to confirm these 
findings to characterize and determine the bioactive components responsible for this effect.

\section{CONCLUSION}

The results of the study indicate that methanolic leaf extracts of three plants (Lindernia ciliata, Phyllanthus reticulatus and Bambusa vulgaris) showed significant alpha amylase and alpha glucosidase enzyme inhibitory activity. Among the three bioactive extracts, Lindernia ciliata showed more activity and it is well comparable with the standard drug acarbose.

\section{ACKNOWLEDGEMENT}

We acknowledge Kakatiya University, Warangal (Telangana), India, for providing all the facilities to perform experimental work.

\section{CONFLICT OF INTEREST}

The authors declare no conflicts of interest.

\section{ABBREVIATIONS}

LCME: Methanolic Extract of Lindernia ciliata; PRME: Methanolic Extract of Phyllanthus reticulatus; BVME: Methanolic Extract of Bambusa vulgaris; IC: Inhibitory Concentration; DM: Diabetes mellitus; GAE: Gallic Acid Equivalent; DMSO: Dimethyl Sulfoxide; DNS: Dinitro Salicylic Acid.

\section{REFERENCES}

1. Ishnava $\mathrm{KB}$, Motisariya DM. In vitro studies on alpha-amylase inhibitory activity of selected ethnobotanical plant extracts and its herbal formulations. Int $\mathrm{J}$
Pharmacogn Chinese Med. 2018;2(3):1-11.

2. Hind L, Nabila B, Sara A, Rabah D. In vitro alpha-amylase and alpha-glucosidase inhibitory activity of Ononis angustissima extracts. J Appl Pharma Sci. 2017;7(2):191-8.

3. Wild S, Roglic G, Green A, Sicree R, King H. Global prevalence of diabetes: estimates for the year 2000 and projections for 2030. Diabetes Care. 2004;27(5):1047-53.

4. IDF Atlas. International Diabetes Federation. Ninth edition. Brussels, Belgium. 2019.

5. Ramprasad R, Madhusudhan S. In vitro alpha-amylase and alpha-glucosidase inhibitory activities of ethanolic extract of Lactua runcinata DC. Der Pharmacia Lettre. 2016;8(5):231-6.

6. Ahlem BS, Sana A, Malek B, Mahjoub A, Fethia S. Antioxidant and alphaglucosidase activities and phytochemical constituents of Chrysanthoglossum trifurcatum (Desf.). Asian Pac J Trop Biomed. 2018;11(4):285-91.

7. Praneetha P, Swaroopa RV, Narsimha RY, Ravi KB. Hepatoprotective studies on methanolic extract of whole plant of Lindernia ciliata. Bangladesh J Pharmacol. 2014;9(4):567-74

8. Swaroopa RV, Farhana B. Evaluation of alpha-amylase and alpha-glucosidase enzyme inhibitory activities of Trichuriella monsoniae Bennet. Int J Pharma Sci Res. 2019;10(3):1342-6.

9. McCue PP, Shetty K. Inhibitory effects of Rosmarinic acid extracts on porcine pancreatic amylase in vitro. Asia Pacific J Clin Nutr. 2004;13(1):101-6.

10. Apostolidis E, Kwon YI, Shetty K. Inhibitory potential of herb, fruit and fungal-enriched cheese against key enzymes linked to type 2 diabetes and hypertension. Innov Food Sci Emerg Technol. 2007;8(1):46-54.

11. Oboh G, Akinyemi AJ, Ademiluyi AO, Bello FO. Inhibition of alpha-amylase and alpha-glucosidase activities by ethanolic extract of Amaranthus cruentus leaf as affected by blanching. Afr J Pharm Pharmacol. 2013;7(17):1026-32.

12. Kwon $\mathrm{Yl}$, Apostolidis $\mathrm{E}$, Kim $\mathrm{YC}$, Shetty K. Health benefits of traditional corn, beans and pumpkin: In vitro studies for hyperglycemia and hypertension management. J Med Food. 2007;10(2):266-75.

13. Nizam UM, Rakib HM, Monir H, Arjyabrata SAHM, Nazmul HAFM, Mahmudul I, et al. In vitro alpha-amylase inhibitory activity and in vivo hypoglycemic effect of methanol extract of Citrus macroptera Montr, Fruit. Asian Pac J Trop Biomed. 2014;4(6):473-9.

14. Oboh G, Akinyemi AJ, Ademiluyi AO. Inhibition of alpha-amylase and alphaglucosidase activities by ethanolic extract of Telfairia occidentalis (fluted pumpkin) leaf. Asian Pac J Trop Biomed. 2012;2(9):733-8.

Article History: Submission Date : 10-03-2020; Revised Date : 22-04-2020; Acceptance Date : 13-05-2020.

Cite this article: Momina SS, Rani VS. In vitro Studies on $\alpha$-Amylase and $\alpha$-Glucosidase Inhibitory Activity of Some Bioactive Extracts. 2020;12(2)Suppl:s72-s5. 